\title{
MODELING EFFICIENCY-EQUITY TRADEOFFS IN RURAL ROADS INVESTMENT RESOURCE ALLOCATION IN OFFINSO DISTRICT OF GHANA
}

\author{
Isaac F. MENSA-BONSU ${ }^{1}$, Seiichi KAGAYA ${ }^{2}$ and Etsuo YAMAMURA ${ }^{3}$ \\ ${ }^{1}$ Member of JSCE, Ph. D. Env. Sci, Lecturer, Department of Planning, Faculty of Environmental and \\ Development Studies, University of Science \& Technology (Kumasi, Ghana) \\ ${ }^{2}$ Member of JSCE, Ph. D. Env. Sci., Associate Professor, Department of Ecological Environmental \\ Science, Graduate School of Environmental Earth Science, Hokkaido University(N10, W5, Kitaku, \\ Sapporo060) \\ ${ }^{3}$ Member of JSCE, Dr. Eng., Professor, Department of Ecological Environmental Science, Graduate \\ School of Environmental Earth Science, Hokkaido University(N10, W5, Kitaku, Sapporo060)
}

\begin{abstract}
In this study the objectives are to define appropriate measures of efficiency and equity in the context of rural road investment and to embrace the efficiency-equity trade-off in mathematical programming model for allocating financial resources for rual road investment at the sub-regional level. In order to solve the problem, it was formulated as selecting some rural roads for investment that lead to the maximum increase in rural accessibility for the greatest number of people, and at the same time minimize the inequity in accessibility distribution within budget constraint, The non-inferior solutions were generated by $\varepsilon$-constraint approach. The preferred solution was obtained by using the importance of link to each agency. This method was applied in the Offinso district, the Ashanti Region of Ghana. As a result we proved that this method was effective to determine the allocation of the road investment in the developing country.
\end{abstract}

Key Words : equity-efficiency tradeoffs, rural Roads investment, rural accessibility, bicriteria optimization

\section{INTRODUCTION}

Road investment, for instance road construction, maintenance, or improvement, is considered as a public service. It has been indicated that equity and efficiency are the main indices of public service performance ${ }^{1) \rightarrow 3}$. A review of the literature, however, reveals that at both the academic and practising levels equity is entirely ignored in quantitative models for rural road investment resource allocation in developing countries.

Models for selecting roads for investment tend to consider only efficiency, notably economic efficiency, with only recent trends towards including social factors. The use of economic efficiency is due greatly to the dominance of the World Bank and other international lending agencies in the development and use of road investment criteria. The needs of these institutions to justify their loans make them employ traditional economic analysis, notably cost-benefit analysis.

It has been pointed out, however, that not only is cost-benefit analysis socially regressive but that in addition it fails to indicate the considerable spatial and regional implications involved in the evaluations. As noted by Leinbach ${ }^{4}$, maximization of wealth which has been the main concern, has led to the maldistribution. For instance a region's transport network could be neglected since the area's production might be lower compared with another area which is more affluent. This is seen as a clear illustration of Myrdal's principle of cumulative causation.

Recent literature indicates a growing awareness, both nationally and internationally, of the need to consider equity as an important factor in development resource allocation. United Nations Development Program (UNDP), for instance, has endorsed the human development imperative for the 1990s, and doubling its search for development approaches that are ecologically sound, self-sustaining, and equitable in their distribution of resources and opportunities ${ }^{5}$.

It is clear in the literature that there is now a great search for ways of adjusting existing rural road investment resource allocation models to reflect, or better reflect, equity considerations. This study is a contribution in that direction. It is 
realized that the few attempts that have been made have not been quite successful. For instance, most of these have been concerned with the social distribution of benefits and, which are even considered outside of the quantitative framework (see for instance the World Bank model ${ }^{6)}$ ).

The most important attempt at incorporating equity consideration into an analytical framework for rural transport planning, perhaps, is that of Nutley ${ }^{7)}$. However, the said study is considered in a developed world setting, U.K., which is different from the problem in hand, that is, rural road investment resource allocation in a developing world setting. Additionally, the efficiency-equity tradeoff is not modeled in the said work.

This study therefore represents, perhaps, the first major attempt to incorporate equity into a quantitative framework for rural road investment analysis. The main objectives are:

1. To define appropriate measures of efficiency and equity in the context of rural road investment.

2. To embrace the efficiency-equity trade-off in a mathematical programming model for allocating financial resources for rural road investment at the sub-regional level.

3. To study the policy implications of trading off equity for efficiency in budget allocation for rural roads improvement.

\section{EFFICIENCY AND EQUITY IN THE CONTEXT OF RURAL ROAD IN- VESTMENT}

\section{(1) Rural Roads}

For the purpose of this study rural roads are defined as those roads whose main function is to provide access to rural areas. They are usually unpaved and are broadly classified into Feeder Roads and Tracks.

Rural road investment comprises maintenance and improvement works as well as new road construction. A recent study by the World Bank has indicated that the main problem facing many developing countries is to salvage roads that have deteriorated severely and to protect newer ones from a similar fate ${ }^{8)}$. Currently, many developing countries have placed an embargo on new road construction and are concentrating efforts on improving existing ones. By rural road investment, therefore, we shall only refer to maintenance and improvement works.

Maintenance and improvement works on rural roads are classified into ${ }^{9)}$ :

1. Routine Maintnance;2.Resurfacing;3.Rehabili- tation and 4. Betterment.

In most developing countries, there is always a gap between rural road investment needs and available resources and, therefore, there arises the problem of deciding which rural roads to select for investment. Also, because rural road investment involves a large commitment of resources there is usually the need to justify the use of the available resources. It therefore becomes expedient to ensure optimal use of available resources. Hence, a natural objective for rural road investment analysis becomes that of ensuring efficiency in the allocation of the limited available resources.

\section{(2) Efficiency}

Analysis of efficiency in the context of resource allocation has been the concern of economists, planners, management scientists, etc. Generally, efficiency measures the ratio of project inputs to outputs. An efficient allocation in that context could be defined as that which would ensure the maximum output (or benefit) within resource constraint.

It is universally recognized in the literature that improvements in transport systems such as roads and railways lead to improved spatial accessibility. It is, in fact, recognized in the literature that transport systems improvements are essentially intended to improve access. Accessibility is thus, an end rather than an impact of transportation planning ${ }^{10)}$.

Efficiency criterion in rural road investment is, therefore, defined in this study as choosing a resource allocation that maximizes accessibility improvement to the greatest number of villagers. Defined this way, an efficient allocation can be obtained via optimization techniques such as Linear Programming. We can define the problem as "select those roads for investment that will result in the maximum increase in accessibility for the greatest number of villagers, and such that it is done within the available budget (resources)".

Rural accessibility is defined as the ability of the villagers to reach or be reached by urban based services and facilities via the transport system. We will base our measure of rural accessibility on the population potential approach. There are a number of expressions for the population potential, but they can be expressed as :

$$
V_{J}=\sum_{i} P_{i} f\left(r_{i j}\right)
$$

Where: $V_{J}=$ the population potential at a point $j$;

$P_{i}=$ the population in zone $i$;

$r_{i j}=$ travel time (or cost) between the zone centroid and the other point $j$;

$f\left(r_{i j}\right)=$ impedance function. 
Rural road improvement leads to a reduction in travel time or cost and hence to improved accessibility. For a rural road network, the total increase in accessibility can be obtained as the difference between the with-and without-improvement situations. This can be expressed $\mathrm{as}^{11)}$ :

$$
\begin{aligned}
A=\sum_{i=1}^{N} P_{i} & {\left[k_{1} X_{i}\left(V_{i o m}\right)^{-1}+k_{2} X_{i}\left(V_{w}\right)^{-1}\right.} \\
& \left.-365 X_{i}\left(V_{\text {iam }}\right)^{-1}\right]
\end{aligned}
$$

Where :

$P_{i}=$ population accessed by link $L_{i}$

$X_{i}=$ length of link $L_{i}$ to be improved;

$V_{\text {iom }}=$ average vehicle speed on road link without road improvement

$V_{\text {iam }}=$ average vehicle speed on road link with road improvement

$V_{w}=$ average walking speed

$k_{1}, k_{2}=$ number of passable and impassable days, respectively, in a year.

It is important, however, to evaluate the distribution of accessibility improvement in terms of equity ;

\section{(3) Equity}

There seems to be no agreement about the concept of equity in the literature. It is, however, indicated that economists and other social scientists since the 1960s have followed a meaning close to equality or fairness ${ }^{12}$.

At the subregional level people, especially rural dwellers, live at varying distances from urban facilities and differ in their ability to reach or be reached by (accessibility to) those facilities. This inequality in accessibility has many serious implications for rural development. For instance, regional distribution of poorest people often show a concentration in remoter areas ${ }^{13)}$. Lack of access for rural dwellers is also believed to keep them in povety and to reinforce the geographical and social inequities ${ }^{14)}$. A study in the Philippines found a strong positive relation between the level of accessibility and each of the major elements of socioeconomic development ${ }^{15)}$.

Rural road improvement resource allocation that is based on the efficiency criteria will tend to perpetuate the existing inequalities in the rural areas. The equitable distribution of the benefits of rural road improvement is raised since costs of rural road improvements are the responsibility of society as a whole, while benefits accrue to one sector.

Ensuring equity in rural road investment resource allocation will not mean equality of accessibility for all villagers in the region, since that is technically infeasible. We argue for a distribution that will lower the inequality in accessibility among the villagers. Thus we need a measure of inequality that is consistent with this aim.

There are several measures of inequality in the literature, but measures of inequity are supposed to satisfy some basic criteria, notable among them being the principle of transfers ${ }^{16)}$. As applied to our study, the principle requires that a transfer of accessibility units from a well-placed group to any relatively worse-off group results in an improvement in the measure.

The Gini coefficient which is widely used as an index of equity is known to satisfy the principle of transfer. We shall therefore base our measure of inequity in rural accessibility on the Gini coefficient. Another reason for deciding on the Gini coefficient is that its interpetation can be linked to the concept of envy in social choice theory where the concept of equity reduces to nonenvy ${ }^{17)}$. This interpretation of the Gini coefficient makes it particilarly meaningful as a measure of equity in the context of rural accessibility distribution.

For our analysis, we consider accessibility improvement resulting from rural road improvement as the objects of equity rather than the investment resources. That is, what is to be distributed fairly is the benefits of rural road improvement. Also the equity units, or the units among which the benefits of rural road improvement are to be distributed fairly, are taken to be villagers (people) rather than villages.

In order to apply the Gini index we categorize the rural dwellers into accessibility groups based on their accessibility problems. People at the same village are taken to be in the same accessibility category, and villages are grouped into categories for the analysis.

Following Mandel $^{18)}$, we express the Gini coefficient as :

$$
G=\sum_{i} \sum_{j>i}\left|q_{j} A_{i}-q_{i} A_{j}\right|\left(\sum_{i} A_{i}\right)^{-1}
$$

Where: $q_{i}=$ the proportion of the total population that is in accessibility category $i$

$A_{i}=$ accessibility problem of villagers in accessibility category $i$.

The accessibility problem, $A_{i}$, is defined as travel impedance and expressed as:

$$
A_{i}=k_{1} X_{i}\left(V_{\text {iom }}\right)^{-1}+k_{2} X_{i}\left(V_{w}\right)^{-1}
$$

Equation (3) becomes an input in our model.

\section{THE ALLOCATION MODEL}

The problem in hand is to allocate the resources for rural road investment based on the two criteria of efficiency and equity. This can be expressed as "select those rural roads for investment that 
will lead to the maximum increase in rural accessibility for the greatest number of people, and at the same time minimize the inequity in accessibility distribution, within budget constraint" .

This problem can be represented as the following bicriteria mathematical programming model:

$$
\begin{aligned}
\operatorname{Max} A= & \sum_{i=1}^{N} P_{i}\left[k_{1} X_{i}\left(V_{\text {iom }}\right)^{-1}\right. \\
& \left.+k_{2} X_{i}\left(V_{w}\right)^{-1}-365 X_{i}\left(V_{\text {iam }}\right)^{-1}\right] \\
\operatorname{Min} G= & \sum_{i} \sum_{j>i} \mid q_{j}\left[k_{1} X_{i}\left(V_{\text {iom }}\right)^{-1}\right. \\
& \left.+k_{2} X_{i}\left(V_{w}\right)^{-1}\right]-q_{i}\left[k_{1} X_{j}\left(V_{\text {iom }}\right)^{-1}\right. \\
& \left.+k_{2} X_{j}\left(V_{w}\right)^{-1}\right] \mid\left\{\sum \left[k_{1} X_{i}\left(V_{\text {iom }}\right)^{-1}\right.\right. \\
& \left.\left.+k_{2} X_{i}\left(V_{w}\right)^{-1}\right]\right\}^{-1} \\
& \text { S.T. } \sum_{i=1}^{N} a_{i} X_{i} \leqq b \\
& 0 \leqq X_{i} \leq U_{i}
\end{aligned}
$$

Where : $a_{i}=$ unit cost of investment;

$U_{i}=$ upper limit of $X_{i}$

$\mathrm{b}=$ available budget.

\section{(1) Solution}

The first step in solving a multi-objective programming (MOP) problem, such as the above, is to generate the non-inferior solutions ${ }^{19}$. A number of techniques are available for generating the noninferior or the Pareto optimal solutions, such as the weighting or parametric method, the scalarization method, and the $\varepsilon$-constraint method.

The $\varepsilon$ - constraint approach ${ }^{20)}$ is applied in this study. We first solve the problem without regard to the equity objective. From the results, we calculate the value of $G$ corresponding to this optimal solution as $G^{*}$. The Pareto optimal solutions can then be obtained by solving problems ( 9 ) - (12) by parametrically varying the values of $\varepsilon$ between $G^{*}$ and for instance 0.1 . The equity objective then becomes a constraint. We then have :

$$
\begin{aligned}
\operatorname{Max} A= & \sum_{i=1}^{N} P_{i}\left[k_{1} X_{i}\left(V_{i o m}\right)^{-1}\right. \\
& \left.+k_{2} X_{i}\left(V_{w}\right)^{-1}-365 X_{i}\left(V_{\text {iam }}\right)^{-1}\right] \\
\text { S.T. } G= & \sum_{i} \sum_{j>i} \mid q_{j}\left[k_{1} X_{i}\left(V_{i o m}\right)^{-1}\right. \\
& \left.+k_{2} X_{i}\left(V_{w}\right)^{-1}\right]-q_{i}\left[k_{1} X_{j}\left(V_{i o m}\right)^{-1}\right. \\
& \left.+k_{2} X_{j}\left(V_{w}\right)^{-1}\right] \mid\left\{\sum _ { i } \left[k_{1} X_{i}\left(V_{i o m}\right)\right.\right. \\
& \left.\left.+k_{2} X_{i}\left(V_{w}\right)^{-1}\right]\right\}^{-1} \leq \varepsilon \\
& \sum_{i=1}^{N} a_{i} X_{i} \leq b \\
& 0 \leq X_{i} \leq U_{i}
\end{aligned}
$$

Following Mandel ${ }^{18)}$ we proceed by multiplying the left-and right-hand sides of (10) through by $\sum_{i}\left[k_{1} X_{i}\left(V_{\text {iom }}\right)^{-1}+k_{2} X_{i}\left(V_{w}\right)^{-1}\right]$ and define : $d_{i j}^{+}-d_{i j}^{-}=q_{j}\left[k_{1} X_{i}\left(V_{i o m}\right)^{-1}+k_{2} X_{i}\left(V_{w}\right)^{-1}\right]$

$$
-\mathrm{q}_{\mathrm{i}}\left[\mathrm{k}_{1} X_{j}\left(V_{\text {iom }}\right)^{-1}+k_{2} X_{j}\left(V_{w}\right)^{-1}\right]
$$

$$
\begin{aligned}
\operatorname{Max} A= & \sum_{i=1}^{N} P_{i}\left[k_{1} X_{i}\left(V_{i o m}\right)^{-1}+k_{2} X_{i}\left(V_{w}\right)^{-1}\right] \\
& \left.-365 X_{i}\left(V_{\text {iam }}\right)^{-1}\right]
\end{aligned}
$$

S.T.

$$
\begin{gathered}
\sum_{i} \sum_{j>i}\left(d_{i j}^{+}+d_{i j}^{-}\right) \leq \varepsilon \sum_{i}\left\{k_{1} X_{i}\left(V_{i o m}\right)^{-1}+k_{2} X_{i}\left(V_{w}\right)^{-1}\right\} \\
d_{i j}^{+}-d_{i j}^{-}-q_{j}\left[k_{1} X_{i}\left(V_{i o m}\right)^{-1}+k_{2} X_{i}\left(V_{w}\right)^{-1}\right] \\
+q_{i}\left[k_{1} X_{j}\left(V_{i o m}\right)^{-1}+k_{2} X_{j}\left(V_{w}\right)^{-1}\right]=0 \\
\sum_{i=1}^{N} a_{i} X_{i} \leq b \\
0 \leq X_{i} \leq U_{i}
\end{gathered}
$$

The next step after the Pareto optimal solutions have been generated, is to obtain the preferred solution. This stage is considered the judgemental phase and requires input from the decision maker. A common approach is the Surrogate Worth Trade-off Method (SWT) originally developed by Haimes and $\mathrm{Hall}^{21}$. It consists of four steps :

1. generate a representative subset of non-inferior solutions ;

2. obtain relevant trade-off information for each generated solution;

3. interact with the decision maker to obtain information about preferences expressed in terms of worth, and

4. retrieve the best compromise solution from the information obtained.

The SWT method as described above assumes a single decision maker. Many real world decisions, however, involve many decision makers ${ }^{22)}$. A number of alternative methods have been suggested. However, as noted in $^{20)}$ most of the suggested structures suffer from the problems emanating from the measurement of individual preferences, interpersonal comparison of those preferences, and their aggregation into a social preference order. It has also been asserted that in practice it may be difficult to solve that class of problems.

A simple evaluation index has, therefore, been developed in this study in order to obtain the preferred solution. It is argued here that all agencies in the district which are involved in rural development should be allowed to participate in the rural road investment decision making. This is in line with the current trend towards intergrated rural development planning where roads are considered to be just one project in the package. The trade-off in this case involves multiple decision makers.

The solution to our trade-off model yields the road links to be selected at each fixed value of the Gini index $G^{*}$. The links selected at each discrete value of $G^{*}$ have been examined using the following index :

Our problem can then be re-written as: 
Table 1 Relevant Features of the Offinso District

\begin{tabular}{|l|l|}
\hline Area & $1504 \mathrm{sq} . \mathrm{km}$ \\
Highway & $73 \mathrm{~km}$ \\
Feeder Roads (38 links) & $135.7 \mathrm{~km}$ \\
Tracks (39 links) & $101.8 \mathrm{~km}$ \\
Population & 81,000 \\
along highway & 54,799 \\
off highway & $26,54.6$ \\
Average Vehicle Speeds & \\
Fe日der roads & $20 \mathrm{~km} / \mathrm{hr}$ \\
Tracks & $15 \mathrm{~km} / \mathrm{hr}$ \\
Passable Days (average) & 350 \\
Feeder Roads & 275 \\
Tracks & \\
$T=\sum_{i=1}^{N} \sum_{j=1}^{K} W_{i j} Y_{i}$
\end{tabular}

Where: $W_{i j}=$ the importance (or utility) of link $i$ to agency $j$.

$N=$ the number of links selected;

$k=$ the number of agencies involved in the

$Y_{i}= \begin{cases}1 & \text { if link } i \text { is selected } \\ -1 & \text { if link } i \text { is not selected }\end{cases}$

The term $W_{i j}$ represents the degree of importance or utility of each link in the network to each agency. This can be obtained by interviewing the rural development agencies operating in the district. This will include political leaders, as well as community representatives and agencies responsible for providing agricultural, health, educational and other socio-economic services to the rural areas. In order to obtain the value of $W_{i j}$ the following scale and scoring system is used:

\begin{tabular}{|c|c|}
\hline Degree of Importance & Score \\
\hline Indeed Critical & 6 \\
\hline Critical & 5 \\
\hline Fairly Critical & 4 \\
\hline Very Important & 3 \\
\hline Important & 2 \\
\hline Fairly Important & 1 \\
\hline Unimportant & 0 \\
\hline
\end{tabular}

The term $Y_{i}$ has been introduced so that the decision makers' satisfaction or agreement with each trade-off can be incorporated. When a link is selected the value of $Y_{i}=1$ which will be interpreted to mean that a decision maker agrees or is satisfied with that selection. When a link is not selected the value of $Y_{i}=-1$ which will also be interpreted to mean that a decision maker is dissatisfied. A decision maker's degree of satisfaction with a selected road link will depend on the degree of importance he attaches to the link. The value of agreement or satisfaction will be measured by the product of $W_{i j}$ and $Y_{i}$. The index $T$ may, therefore, be interpreted as the total agreement or satisfaction with the road selection con- stituting a given non-inferior solution. The noninferior solution which gives the highest value of $T$ may, therefore, be considered as the preferred solution.

\section{APPLICATION TO THE OFFINSO DISTRICT IN GHANA}

The Offinso district is a sub-region of the Ashanti Region of Ghana. Its relevant features are summarized in Table 1 . Nearly all the facilities in the district are located along a highway which traverses the district more or less centrally. The off-highway villagers are connected to the highway by a network of feeder roads and tracks. These rural roads are in poor condition thus, posing accessibility problems to the off-highway villagers who need access to the highway in order to enjoy the facilities and services along the highway. The incidence of accessibility burden is, however, unequal since the villages are at varying distances from the highway and road conditions are also at different degrees of deterioration.

The problem is to allocate a budget of 120 million Cedis for improving the condition of rural roads in the district such that it will lead to the maximum increase in accessibility and at the same time to try to minimize the inequity in the distribution of accessibility burden. Tracks are to be upgraded to gravel standards at an average cost of 3.5 million Cedis per kilometer.

We employ the model represented by (14) (18). The parameters can be obtained from Table 1. Also, $V_{\text {iam }}$ and $V_{w}$ are taken to be $60 \mathrm{~km} / \mathrm{hr}$ and $4 \mathrm{~km} / \mathrm{hr}$ respectively. For the purpose of the analysis, the feeder roads have been divided into 38 links and the tracks into 39 links.

We first solve the problem represented by (9), (11) and (12). Thus, with our parameter values, we solve the following LP:

$$
\begin{gathered}
\operatorname{Max} Z=\sum_{i=1}^{38} 15.2 P_{i} X_{i}+\sum_{i^{*}=1}^{39} 34.75 P_{i *} X_{i *} \\
\text { S.T. } 0 \leq \sum_{i=1}^{38} 2 X_{i}+\sum_{i^{*}=1}^{39} 2 X_{i *} \leq 120 \\
0 \leq X_{i}, \quad X_{i *} \leq U
\end{gathered}
$$

Where : $X_{i}$ and $X_{i *}$ represent feeder road and track respectively.

The Gini coefficient associated with the optimal solution to the above LP is 0.54759084 .

The villagers have been categorized into 11 accessibility groups based on their accessibility burden (reaching the highway). People from villages which fall within the same range of accessibility burden, form one category.

To obtain the Pareto optimal solutions we solve 


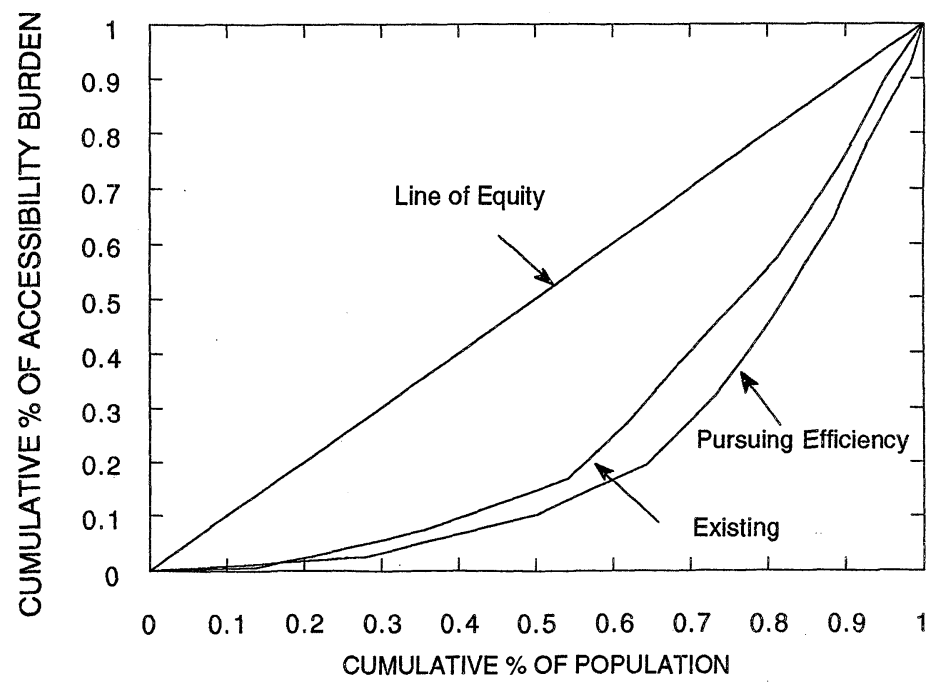

Fig. 1 Distribution of Accessibility Burden

the following problem parametrically varying the values of $\varepsilon$ from 0.5 to 0.1 .

$$
\text { Max } Z=\sum_{i=1}^{38} 15.2 P_{i} X_{i}+\sum_{i^{*}}^{39} 34.75 P_{i *} X_{i *}
$$

S.T.

$$
\begin{aligned}
& \sum_{i} \sum_{j>i}\left(d_{i j}^{+}+d_{i j}^{-}\right) \leq \varepsilon \sum_{i}\left\{k_{1} X_{i}\left(V_{i o m}\right)^{-1}\right. \\
& \left.+k_{2} X_{i}\left(V_{w}\right)^{-1}\right\} \\
& d_{i j}^{+}-d_{i j}^{-}-q_{j}\left\{k_{1} X_{i}\left(V_{i o m}\right)^{-1}\right. \\
& \left.+k_{2} X_{i}\left(V_{w}\right)^{-1}\right\}+q_{i}\left\{k_{1} X_{j}\left(V_{i o m}\right)^{-1}\right. \\
& \left.+k_{2} X_{j}\left(V_{w}\right)^{-1}\right\}=0 \\
& 0 \leq \sum_{i=1}^{38} 2 X_{i}+\sum_{i^{*}=1}^{39} 3.5 X_{i *} \\
& 0 \leq X_{i}, X_{i *} \leq U
\end{aligned}
$$

There are 11 categories in all, giving us $\frac{11 \times 10}{2}$ constraints as the expansion of (24) alone. The expansion of model (22) - (26) for just one value of $\varepsilon$ fills nine A4-size pages (single spacing), and cannot be provided here owing to space limitation. The problem was solved using Linear Interactive and Discrete Optimizer (LINDO) package, for values of

$\varepsilon=0.5,0.45,0.40,0.35,0.30,0.25,0.20,0.15$, and 0.10 .

\section{RESULTS AND IMPLICATIONS}

The existing distribution of accessibility burden in the district can be seen in Fig. 1. When only efficiency is considered in the allocation, inequity in the distribution of accessibility burden increases as seen in Fig. 1. The implication is that pursuing the efficiency objective worsens inequity in the distribution of accessibility burden. This confirms earlier observations. Recognizing the rural development implications of such an allocation policy, it will perhaps be advisable to trade off some efficiency for equity.

The Pareto optimal solutions obtained by parametrically solving problem (22) - (26) can help make such a trade off. The implications in terms of road selection can be identified. Considering only efficiency, the road selection is indicated in Fig. 2. It is noteworthy that four tracks are included in the selection. In many past studies based on the conventional engineering economy, tracks are not even considered as candidates for selection.

Some results of the trade-off and the road selection implications are summarized in Table 2.

It can be realized from Table 2 that if we aim at a 27 per cent reduction of inequity, then efficiency will be reduced by a mere 1.5 per cent. Feeder road link 33-32 will then be substituted by feeder road link $64-\mathrm{J} 4$. The loss, in terms of efficiency, of reducing inequity seems to increase at a higher rate as we approach the line of equity.

The results of the evaluation of the Pareto optimal solutions, in search of the preferred solution, are provided in Table 3. The cells of this table indicate the values of $W_{i} Y_{i}$ for each agency. Based on the degree of importance the agencies attach to each link, and using our evalution index, the preferred solution is provided at the point where the Gini coefficient is 0.2 , and accessibility gain is $1,425,060$ person-hours. This outcome seems to support trading off efficiency for equity. 


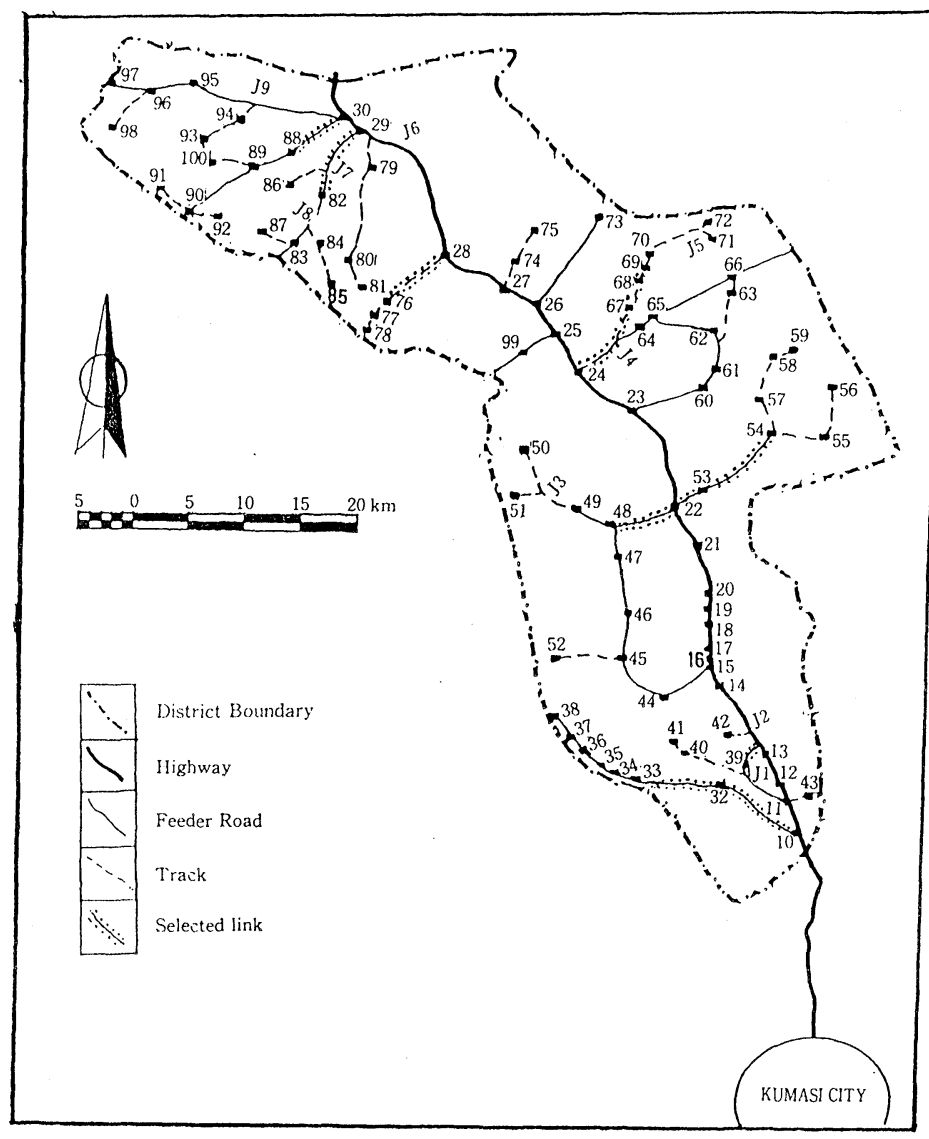

Fig. 2 Road Selection based solely on Efficiency

Table 2 Efficiency-Equity Tradeoffs and the Road Selection Implications

\begin{tabular}{|c|c|c|c|l|}
\hline INEQUITY & $\begin{array}{l}\% \\
\text { DECREASE }\end{array}$ & ACCESSIBILITY & $\begin{array}{l}\% \\
\text { DECREASE }\end{array}$ & ROAD SELECTION POLICY \\
\hline 0.547591 & - & $2,154,730$ & - & SEE FIGURE 2 \\
\hline 0.5 & 8.7 & $2,154,730$ & 0 & UNCHANGED \\
\hline 0.45 & 17.8 & $2,154,730$ & 0 & UNCHANGED \\
\hline 0.40 & 26.95 & $2,122,746$ & 1.5 & LINK33-32 REPLACED BY 64-J \\
\hline 0.35 & 36.1 & $2,048,052$ & 4.95 & $\begin{array}{l}\text { LINKS 33-32AND69-68 REPLACED BY } \\
60-23,43-11,64-\mathrm{J}\end{array}$ \\
\hline 0.30 & 45.2 & $1,908,156$ & 11.4 & $\begin{array}{l}\text { LINKS 33-32,69-68,68-67,76-28, REPLACED } \\
\text { BY 60-23,43-11,64-J,44-15,65-64,74-27 }\end{array}$ \\
\hline 0.25 & 54.3 & $1,674,604$ & 28.7 & $\begin{array}{l}\text { LINKS 33-32,69-68,68-67,76-28,82-J, } \\
\text { REPLACED BY 60-23,43-11,64-J,65-64,74- } \\
27,44-15,42-\mathrm{J}, 79-\mathrm{J}\end{array}$ \\
\hline 0.20 & 63.5 & $1,425,060$ & 33.9 & $\begin{array}{l}\text { LINKS 33-32,69-68,68-67,76-28,82-J,67-J,32-10 } \\
\text { REPLACED BY 60-23,43-11,64-J,65-64,74- } \\
27,44-15,42-\mathrm{J}, 79-\mathrm{J}, 99-25,78-77\end{array}$ \\
\hline 0.15 & 72.6 & $1,167,385$ & 45.8 & $\begin{array}{l}\text { LINKS 33-32,69-68,68-67,76-28,82-J,67-J,32-10 } \\
53-22, \mathrm{~J}-24, \mathrm{REPLACED} \text { BY 60-23,43-11,64- } \\
\mathrm{J}, 65-64,74-27,44-15,42-\mathrm{J}, 79-\mathrm{J}, 99-25,78-77,80- \\
79,94-\mathrm{J}, 93-94,73-26\end{array}$ \\
\hline 0.1 & 81.738 & 872,730 & 59.5 & $\begin{array}{l}\text { LINKS 33-32,69-68,68-67,76-28,82-J,67-J,32-10 } \\
53-22, \mathrm{~J}-24,54-53, \mathrm{~J}-29,88-30 \text { REPLACED BY } \\
60-23,43-11,64-\mathrm{J}, 65-64,74-27,44-15,42-\mathrm{J}, 79- \\
\mathrm{J}, 99-25,78-77,80-79,94-\mathrm{J}, 93-94,73-26,46-43,56- \\
55,72-\mathrm{J}, 85-84\end{array}$ \\
\hline
\end{tabular}


Table 3 Evaluation of Non-Inferior Solutions

\begin{tabular}{|r|l|c|c|c|c|c|c|c|c|}
\hline & \multicolumn{1}{|c|}{ AGENCY } & $G=0.5$ & $G=0.4$ & $G=0.35$ & $G=0.3$ & $G=0.25$ & $G=0.20$ & $G=0.15$ & $G=0.10$ \\
\hline 1 & EDUCA. DIRECTOR & -160.00 & -162.00 & -154.00 & -148.00 & -150.00 & -146.00 & -150.00 & -158.00 \\
\hline 2 & EDUCA. SUPPLIES & -136.00 & -132.00 & -124.00 & -116.00 & -116.00 & -112.00 & -116.00 & -116.00 \\
\hline 3 & EDUCA. INSPEC & -153.00 & -163.00 & -155.00 & -151.00 & -157.00 & -153.00 & -176.00 & -191.00 \\
\hline 4 & EDUCA.PERSONNEL & -159.00 & -163.00 & -155.00 & -151.00 & -155.00 & -149.00 & -155.00 & -155.00 \\
\hline 5 & ANIMAL PRODUC & -162.00 & -168.00 & -162.00 & -152.00 & -172.00 & -156.00 & -150.00 & -168.00 \\
\hline 6 & AGRICULT. MIN & -245.00 & -245.00 & -235.00 & -225.00 & -225.00 & -215.00 & -215.00 & -215.00 \\
\hline 7 & AGRIC. PLANNING & -294.00 & -294.00 & -282.00 & -270.00 & -270.00 & -258.00 & -258.00 & -258.00 \\
\hline 8 & EXTENSION & -119.00 & -117.00 & -113.00 & -109.00 & -109.00 & -105.00 & -105.00 & -105.00 \\
\hline 9 & FOOD DISTRIBU & -245.00 & -245.00 & -235.00 & -225.00 & -225.00 & -215.00 & -215.00 & -215.00 \\
\hline 10 & ROAD TRANSPORT & -188.00 & -192.00 & -182.00 & -176.00 & -186.00 & -184.00 & -192.00 & -202.00 \\
\hline 11 & ENV.HEALTH & -104.00 & -104.00 & -100.00 & -96.000 & -96.000 & -94.000 & -96.000 & -98.000 \\
\hline 12 & FORESTRY & -67.000 & -67.000 & -65.000 & -63.000 & -63.000 & -67.000 & -77.000 & -89.000 \\
\hline 13 & DISTRICT ADMIN & -245.00 & -245.00 & -235.00 & -225.00 & -225.00 & -215.00 & -215.00 & -215.00 \\
\hline 14 & RURAL BANK & -294.00 & -294.00 & -285.00 & -270.00 & -270.00 & -258.00 & -258.00 & -258.00 \\
\hline 15 & COMMERCIAL BANK & -107.00 & -117.00 & -111.00 & -109.00 & -117.00 & -119.00 & -123.00 & -133.00 \\
\hline 16 & PRIM.HEALTH CAR & -85.000 & -85.000 & -79.000 & -77.000 & -77.000 & -73.000 & -73.000 & -79.000 \\
\hline 17 & MIN. OF HEALTH & -104.00 & -102.00 & -96.000 & -92.000 & -90.000 & -86.000 & -88.000 & -92.000 \\
\hline 18 & EPIDEMIOLOGY & -65.000 & -65.000 & -59.000 & -49.000 & -53.000 & -51.000 & -55.000 & -63.000 \\
\hline 19 & MAT\& CHD HEALTH & -139.00 & -143.00 & -135.00 & -131.00 & -143.00 & -141.00 & -151.00 & -171.00 \\
\hline 20 & PROD. BUY. CO. & -294.00 & -294.00 & -282.00 & -270.00 & -270.00 & -258.00 & -258.00 & -258.00 \\
\hline 21 & ALL & -3365.0 & -3352.0 & -3244.0 & -3115.0 & -3169.0 & -3055.0 & -3125.0 & -3239.0 \\
\hline
\end{tabular}

\section{CONCLUSION}

The literature has indicated that there is now a great need to consider equity in rural road investment resource allocation, but this study represents, perhaps, the first major attempt to incorporate efficiency and equity into a unified model for rural road investment analysis. The efficienccyequity trade-off has been modeled via MOP. The Pareto optimal solutions generated by the model represents alternative allocation policies.

A simple but effective method has been provided for deriving the preferred solution. It has the important aspect of providing a framework for the participation of all agencies involved in rural road investment decision making. This is crucial since despite the emphasis in the literature on the importance of beneficiary participation in investment decision making, to date, there seems to be no rural roads appraisal technique which intrinsically considers beneficiary participation in investment decision making.

The applicability of the model developed in this study has been illustrated with the case of the Offinso district in Ghana. It has been indicated that considering only efficiency in the allocation of resources for rural road investment will tend to worsen the inequity in accessibility distribution. The model was used to generate alternative allocation policies. Our model could, perhaps, help in addressing the issue of beneficiary participation which has recently attracted more attention in the allocation of rural road investment resources in developing countries. Further testing of the model in other regions is considered desirable.

\section{REFERENCES}

1) Sava, E.S.: On Equity in Providing Public Service, -Management Science, Vol. 24, No. 8, pp. 800-807, April 1978.

2) Bodily, Samuel E. : Police Sector Design incorporating Preferences for Equality and Efficiency, Management Science, Vol. 24, No. 12, pp. 1301-1313, August 1978.

3) Brill, E. Downey: The use of Optimization Models in Public-Sector Planning, Management Science, Vol. 25, No. 5, pp413-421, May 1979.

4) Leinbach, T.R.: Transport Evaluation in Rural Development: An Indonesian Case Study, Third World Pla nning Review, Vol. 5, No. 1, pp. 23-35, Feb. 1983.

5) Gall, Peter: What really Matters:Human Development in UNDP World Development, May 1990.

6) Carnemark, C., J. Biderman and D. Bovert: Economic Analysis of Rural Road Projects, Staff Working Paper No. 241, The World Bank, Washington, D.C., 1976.

7) Nutley, S.D.: Planning for Accessibility Provision: Welfare, Economic and Equity, Environment and Planning $A$, Vol. 16, pp. 357-376, 1984.

8) World Bank, Road Deterioration in Developing Countries: Causes and Remedies, The World Bank, Washington D.C., 1988.

9) Paterson, William D.O.:Road Detetioration and Maintenance Effects, The Johns Hopkins University Press, Oxford, 1986.

10) De Boer, E.: Introduction, in De Boer (ed), Transport Sociology: Social Aspects of Transportation Planning, Pergamon Press, Oxford, 1986.

11) Mensa-Bonsu, I.F., S. Kagaya and E. Yamamura Rural Roads Investment Allocation via Linear Programming: A Case Study of Offinso District in Ghana, Hokkaido Toshi Gakkai, Vol. 29, pp. 23-30, April 1992.

12) Allan, M.F.: Equity in Eatwell J. et al (ed) The New Palgrave A Dictionary of Economics, Vol, $2 \mathrm{E}$ to J, The 
McMillan Press Ltd., London, 1987, pp183-184

13) Chambers, R.:Rural Development:Putting the Last First, Longman Scientific and Technical, Essex, 1991.

14) Rondinelli, D.A.: Equity, Growth and Development, Journal of American Planning Association, Vol. 51, pp 438-448, 1985.

15) Mazlumolhosseini, A.: Relationships between Social and Economic Development and Access to Rural Roads in Developing Countries, Transportation Research Record 1274, pp179-194.

16) Allison, Paul D.: Measures of Inequality, American Sociological Review 1978, Vol. 43 (Dec) pp. 965-880.

17) Sen, Amatya: Social Choice Theory in K.J. Arrow and M.D. Instriligator (eds), Handbook of Mathematical Economics Vol III, Elsevier Science Publishers, Amsterdam, 1986.

18) Mandell, M.B.: Modeling Effectiveness-Equity Tradeoff in Public Service Delivery Systems, Management
Science, Vol. 37, No. 4, pp. 467-482, April 1991.

19) Seo, Fumiko and M. Sakawa:Multiple Criteria Decision Analysis in Regional Planning, D. Reidel Publishing Company, Dordrecht, 1988.

20) Chankong, V. and Y.Y. Haimes:Multiobjective Decision Making: Theory and Methodology, Nort-Holland, New York, 1983.

21) Haimes, Y.Y. and W.A. Hall:Multiobjectives in Water Resource Systems Analysis: the Surrogate Worth Trade-off Method, Water Resources Research 10, 616-624.

22) Kagaya, Seiichi : Multiobjective Analysis for Determining Optimal Scale of Residential Development in Flood-prone Urban Areas, The Korean Journal of Regional Science, Vol. 3, pp. 95-110, December 1987.

(Received November 15,1993)

\section{ガーナオフィンソ地区の地方道路投資配分における効率性公平性トレードオフモデリング}

$$
\text { アイザック F メンサボンス・加賀屋誠一・山村悦夫 }
$$

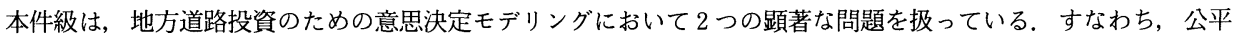
性と効率性のトレードオフ問題と意思決定での受益者参加の問題である. このような, 問題を統合化するモデリン グ手法の開発と，その地方道路投資問題への適用がここでの目的で，それらの問題は，多基準数理計画プログラミ ング問題としてモデル化された．そして，それは投資によるアクセスビリティの増加量を最大化する目的と，分布 するアクセスビリティ格差最小の目的を同時に満たすように表現，定式化された。 $\varepsilon$ 制約法が，非少解の集合を一 般化するために用いられ，また選好解の決定は，地方開発機関に対する各りンクの重要度の情報を集約し，その重 要度を基にして非劣解から選好するプロセスを導入することでおこなわれた。 その結果, 道路投資のための意思決 定で, 各機関の参加が図られた。このような方法は, ガーナオフィンソ地区に適用され, 実証分析がおこなわれ た。 その結果, 開発途上国の道路投資決定法に有効であることが明らかにされた。 